DOI 10.2478/linpo-2018-0003

\title{
Learner autonomy dimensions: What motivated and unmotivated EFL students think
}

\section{Craig Gamble ${ }^{1} \&$ Michael Wilkins $^{1} \&$ Jonathan Aliponga ${ }^{2}$ \& Yakuko Koshiyama ${ }^{2}$ \& Keiko Yoshida ${ }^{3}$ \& Shirley Ando $^{4}$}

\author{
${ }^{1}$ Language Center, Kwansei Gakuin University \\ ${ }^{2}$ Department of English Communication, Kansai University of International Studies \\ ${ }^{3}$ Institute for Language and Culture, Konan University \\ ${ }^{4}$ Institute of International Education, Otemae University \\ gamble@kwansei.ac.jp, michaelrwilkins@kwansei.ac.jp, alipongaj@kuins.ac.jp, \\ ykoshiyama@kuins.ac.jp, keiko@center.konan-u.ac.jp, shirley@otemae.ac.jp
}

\begin{abstract}
Craig Gamble \& Michael Wilkins \& Jonathan Aliponga \& Yakuko Koshiyama \& Keiko Yoshida \& Shirley Ando. Learner autonomy dimensions: What motivated and unmotivated EFL students think. The Poznań Society for the Advancement of Arts and Sciences, PL ISSN 0079-4740, pp. 33-47

To counter the misunderstandings that students from East Asian countries like Japan are less autonomous than learners from other cultural backgrounds, this exploratory research examined Japanese university students' attitudes toward their own responsibility and ability to study English autonomously. Student motivation was observed specifically to determine how students perceived their learning inside and outside the classroom. In this study, 958 students from 12 universities across Japan participated in a 24-item adapted questionnaire on learner autonomy. Based on the data collected, slight to not significant differences were revealed regarding students' perceptions of responsibility to perform autonomous learning tasks. However, with regard to perceived ability to perform autonomous learning tasks, there were significant differences as motivated students demonstrated a far greater confidence in their capacity to be involved in their own learning than unmotivated students, yet they did not necessarily act on their ability to do so. These findings and their implications are explored and discussed.
\end{abstract}

Keywords: learner autonomy, learner perceptions, student motivation, university teaching

\section{Introduction and background}

The ability to assume responsibility for one's own learning is the definitive definition of learner autonomy (Holec 1981). To become an autonomous learner it is expected that one will: set personal learning goals, identify learning strategies to achieve such goals, develop individual study plans, recognize and select relevant resources and support, and assess and reflect on one's own progress. Little (1995: 176) supports this by affirming that "learners who take responsibility for their own learning are more likely to achieve 
their learning targets". However, autonomous language learning outcomes may be influenced by preconceived beliefs by learners themselves and "the beliefs learners hold may either contribute or impede the development of their potential for autonomy" (Cotterall 1995: 196). Cotterall's supposition of such predetermined perceptions is conclusively reinforced by Bandura's (1977) 'perceived self-efficacy' theory. 'Perceived self-efficacy" is defined as the beliefs people hold of their ability to perform and accomplish meaningful results that influence their lives. Thus, learners who have higher self-assurance of themselves and their abilities will believe that challenging tasks are there to be mastered. Conversely, learners who doubt their abilities will perceive difficult tasks as impossible obstacles (Bandura 1977). Therefore, self-assessment of one's abilities greatly influences the feeling of responsibility to complete autonomous learning tasks such as setting goals and thus making actual significant progress in and outside the classroom.

In addition to the idea of preconceived behaviors that may influence learner autonomy, significant pedagogical differences between Eastern and Western educational contexts have also been studied as possible deterrents for autonomy among Asian learners (Biggs 1994, as cited in Sert 2006: 184; Lengkanawati 2017; Liu 1998; Oxford 2008). Among the claims made of these cultural learning differences, Liu (1998) postulates that within cultures with a traditional conformity to authority, a teacher is the purveyor of knowledge in the classroom and not a facilitator of learning. A specific example of one such belief is the expectations of the proper role of the teacher held by learners, which has a strong precedence in Asian culture. Cotterall (1995) stresses this considerably in her literature review of two different studies by Haughton \& Dickinson (1988) and Kumaravadivelu (1991). Cotterall concludes that learners often perceive teachers as authority figures, central to the learning process that takes place in and out of the classroom, and that this perspective clearly contradicts the concept of autonomy. This point of view is further supported by Biggs's (1994) assertion that learners are more often discouraged from taking responsibility for their own learning because of the educational approaches established in the East. These beliefs are prominently reinforced when considering teacher perceptions of their students' abilities and responsibilities as learners. Ustunluoglu's (2009) study of 24 teachers of English in Turkey revealed that they perceive taking most of the responsibility for learning as they do not believe the students have the ability to do it themselves. This is consistent with the study by Aliponga et al., who concluded that the majority of 251 Japanese high school teachers of English believe "their students have poor ability to carry out autonomy-related classroom tasks" (2015: 37). In both studies, the consensus was that the teachers failed to create an environment that encouraged students to practice or engage in autonomous learning tasks. The suppositions made by the studies discussed here can be summed up by Oxford (2008: 50), who concludes that the Western concept of individual autonomy is not easily assimilated into many traditional Asian cultures, where classroom obedience and social factors, such as group cohesion, take precedence.

Although the aforementioned studies present valid points on potential learner autonomy limitations in the East, little empirical research has considered students' own perceptions of their learning within such educational contexts. One significant study available is by Littlewood (2000), who compared student perceptions of autonomy between 
eight Asian countries and three European countries. From his study Littlewood concluded that Asian students demonstrated just as much desire for autonomy as their European counterparts. Littlewood specifically claims that Asian learners do not necessarily perceive the teacher as an authority figure only or that they are content on being passive learners in the classroom despite Asian learners being stereotyped as obedient and passive learners. In fact, Littlewood continues this point of view by stating, "this is more likely to be a consequence of the educational contexts that have been provided for them than of any inherent dispositions of the students themselves" (2000: 33). Holden \& Usuki's (1999) study, which focused explicitly on Japanese students' perceptions of learning autonomously, supports Littlewood's conclusions by claiming that the educational system as a whole is to blame as the learning environments created actually discourage autonomous learning rather than the supposed intrinsic passive behavior of the learners themselves.

While more recent studies provide some important postulations regarding learner autonomy research within Asia (Lengkanawati 2017; Orawiwatnakul \& Wichadee 2017; Ou 2017; Tran \& Duong 2018), our research is more along the lines of the studies conducted by Holden \& Usuki (1999) and Ustunluoglu (2009). While Holden and Usuki asked students (through 10 open-ended interview questions) to evaluate their own learning beliefs as well as their expectations for learning and their expectations of their teachers; our study adopted a quantitative questionnaire based on Ustunluoglu's (2009) research in Turkey. Items in this questionnaire asked students to give their opinions of their responsibilities and what they felt they were capable of accomplishing inside and outside the classroom. The focus of this study is to determine students' perceptions of the two main dimensions of learner autonomy, responsibility and ability, as identified by Littlewood (1999).

Responsibility, as emphasized by Littlewood (1999), is one of the main necessities of autonomous learning, therefore, students must take responsibility for their own learning because, when it comes down to it, the students themselves are the ones who do the learning. However, students need to also develop the ability to continue learning after their formal education. Additionally, an alternative definition of taking responsibility as learners is taking ownership (partial or total) of some of the many processes which have traditionally belonged to the teacher. These processes include deciding on learning objectives, selecting learning methods, and evaluating the learning process.

Ability is the second dimension of learner autonomy identified by Littlewood. It is the students' capability to successfully complete the processes or tasks connected to responsibility. According to Scharle \& Szabo (2000), developing this generalized ability is essential in order for students to take responsibility for their own learning. Scharle and Szabo also argue that motivation, especially intrinsic - which Deci \& Ryan (1985) explain as the performance of a task where the rewards are gained simply through the process of task completion notwithstanding of any external rewards - is a key component of responsibility. Thus, as far as this study is concerned, students' perceptions of responsibility for and ability to perform autonomous learning tasks according to their motivational levels are the main focus of the study. The specific questions it sought to answer are:

1. Is there a significant difference between Motivated Students (M) and Unmotivated Students (UM) in terms of the perception of their responsibility to perform autonomous learning tasks? 
2. Is there a significant difference between Motivated Students (M) and Unmotivated Students (UM) in terms of the perception of their ability to perform autonomous learning tasks?

\section{Method}

\subsection{Participants}

This study utilized convenience sampling as colleagues and acquaintances met through professional conferences or associations that teach English courses at Japanese universities were contacted to gather participants. Initial data were collected from a total of 1,021 participants with varying majors from twelve universities across Japan. Data from 63 participants were removed due to inconsistent responses or failing to complete all sections of the questionnaire. As a result, 958 participants remained: 424 male and 534 female. Of the total participants, 446 were in their first year, 264 in their second year, and 248 were in third year of study. Additionally, 415 participants attend a public university while 543 attend a private university. Participants of this study were either English majors taking obligatory English courses or electives or non-English majors who were required to take basic English courses. Finally, 667 participants self-identified themselves as being motivated, while 291 identified as unmotivated respectively.

\subsection{Instruments}

The questionnaire employed in this study was designed to compare the results with research conducted in culturally similar circumstances and was adapted from the one utilized by Ustunluoglu (2009) in Turkey. In turn, Ustunluoglu's questionnaire was based on the one used by Chan et al. (2002) to gather data from university students in Hong Kong. Chan et al.'s questionnaire was based on input from Deci (1995), and Deci \& Ryan (1985). The original 52-item questionnaire of Deci and Ryan contained 4 sections, all of which are related to autonomous learning: students' perception of their responsibilities, students' perception of their abilities, students' perception of their motivation level, and the activities they engage in both inside and outside the classroom. After pilot testing using a principal components analysis with a varimax rotation, only 42 -items were retained in the Ustunluoglu's questionnaire.

For the purpose of this study, the researchers directly adopted statement items plus the items on the personal background from Ustunluoglu's questionnaire. However, the analysis of data was limited only to students' perceptions of their responsibilities and abilities according to their motivation level. As the questionnaire was to be administered in Japan, it was first translated into Japanese and then reverse-translated by two Japanese professors of English to ensure content validity and to avoid any misunderstanding which might result from language differences. Then it was administered to a test group of 35 university students wherein they were asked to comment on any ambiguous items in order to ensure its comprehensibility and content validity. The questionnaire was then revised incorporating the students' feedback and the final version was created. 
The resultant questionnaire utilized in this study is divided into three sections and comprises a total of 20 statements as well as several demographic data questions. Section 1 relates to participants' perceptions of responsibility, while Section 2 reports on ability, and both sections ask about ensuring students' progress during English lessons. Each section consists of 10 statements. Response choices for Section 1 are Yours, Your Teacher's or Both. Responses in Section 2 were scored from 1 Very Poor to 5 Very Good on a Likert scale. However, for ease of interpretation and data analysis, data were categorized into two ability variables: able to and not able to. Section 3 relates to demographic data, such as year in school and gender. In addition, participants are asked to self-identify their motivation level for learning English.

\subsection{Results}

Chi square $\left(\chi^{2}\right)$ was utilized to describe the variables in this study, namely: students' perceptions of their responsibility and students' perceptions of their ability grouped according to motivation levels. Significant difference was found for these two variables.

Table 1 below summarizes the results relating to the responsibility for performing autonomous learning tasks. According to the data, only two tasks revealed significant differences between the perceptions of Motivated (M) participants and Unmotivated (UM) participants: Q3, responsibility to stimulate interests $\left(\chi^{2}=13.664, \mathrm{df}=3, \mathrm{p}<.01(.003)\right)$, and Q10, to evaluate learning $\left(\chi^{2}=11.297^{*}\right.$, df $=4$, *p $\left.<.05(.023)\right)$.

Table 1: Perceptions of responsibility

\begin{tabular}{|c|c|c|c|c|c|c|}
\hline \multicolumn{2}{|r|}{ Autonomy-Related Tasks (Responsibility) } & $\begin{array}{l}\text { Moti- } \\
\text { vation } \\
\text { Level }\end{array}$ & $\begin{array}{l}\text { SR } \\
\text { n }(\%)\end{array}$ & $\begin{array}{c}\text { TR } \\
\text { n }(\%)\end{array}$ & $\begin{array}{c}\mathrm{B} \\
\mathrm{n}(\%)\end{array}$ & Note \\
\hline \multirow{2}{*}{ Q1 } & \multirow{2}{*}{$\begin{array}{l}\text { Students' perceptions of their responsibility } \\
\text { to make progress during English lessons }\end{array}$} & M & $254(37.8 \%)$ & $69(10.3 \%)$ & $344(51.2 \%)$ & \multirow{2}{*}{$\mathrm{x}^{2}=4.213, \mathrm{df}=3, \mathrm{p}>.05(.239)$} \\
\hline & & UM & $120(41.2 \%)$ & $41(14 . \%)$ & $130(44.6 \%)$ & \\
\hline \multirow{2}{*}{ Q2 } & \multirow{2}{*}{$\begin{array}{l}\text { Students' perceptions of their responsibility } \\
\text { to ensure progress outside class }\end{array}$} & M & $492(73.2 \%)$ & $58(8.6 \%)$ & $117(17.5 \%)$ & \multirow{2}{*}{$\mathrm{x}^{2}=2.412, \mathrm{df}=4, \mathrm{p}>.05(.660)$} \\
\hline & & UM & $203(69.7 \%)$ & $34(11.6 \%)$ & $54(18.5 \%)$ & \\
\hline \multirow{2}{*}{ Q3 } & \multirow{2}{*}{$\begin{array}{l}\text { Students' perceptions of their responsibility } \\
\text { to stimulate interests }\end{array}$} & M & $129(19.2 \%)$ & $240(35.9 \%)$ & $298(44.3 \%)$ & \multirow{2}{*}{$\mathrm{x}^{2}=13.664^{*}, \mathrm{df}=3, \quad * \mathrm{p}<.01(.003)$} \\
\hline & & UM & $43(14.7 \%)$ & $142(48.7 \%)$ & $106(37.1 \%)$ & \\
\hline \multirow{2}{*}{ Q4 } & \multirow{2}{*}{$\begin{array}{l}\text { Students' perceptions of their responsibility } \\
\text { to identify weakness }\end{array}$} & M & $325(48.4 \%)$ & $79(11.8 \%)$ & $263(39.1 \%)$ & \multirow{2}{*}{$\mathrm{x}^{2}=1.335, \mathrm{df}=3, \mathrm{p}>.05(.721)$} \\
\hline & & UM & $142(48.7 \%)$ & $28(9.8 \%)$ & $121(41.5 \%)$ & \\
\hline \multirow{2}{*}{ Q5 } & \multirow{2}{*}{$\begin{array}{l}\text { Students' perceptions of their responsibility } \\
\text { to decide objectives of class }\end{array}$} & M & $131(19.6 \%)$ & $261(38.8 \%)$ & $275(41.2 \%)$ & \multirow{2}{*}{$\mathrm{x}^{2}=2.887, \mathrm{df}=3, \mathrm{p}>.05(.409)$} \\
\hline & & UM & $63(21.6 \%)$ & $124(42.6 \%)$ & $104(35.7 \%)$ & \\
\hline \multirow{2}{*}{ Q6 } & \multirow{2}{*}{$\begin{array}{l}\text { Students' perceptions of their responsibility } \\
\text { to decide what to learn next in the lesson }\end{array}$} & M & $87(12.9 \%)$ & $335(49.9 \%)$ & $245(36.7 \%)$ & \multirow{2}{*}{$\mathrm{x}^{2}=3.829, \mathrm{df}=3, \mathrm{p}>.05(.281)$} \\
\hline & & UM & $35(12 \%)$ & $167(57.3 \%)$ & $89(30.5 \%)$ & \\
\hline \multirow{2}{*}{ Q7 } & \multirow{2}{*}{$\begin{array}{l}\text { Students' perceptions of their responsibility } \\
\text { to choose activities to use in lessons }\end{array}$} & M & $76(11.3 \%)$ & $355(53.2 \%)$ & $236(35.1 \%)$ & \multirow{2}{*}{$\mathrm{x}^{2}=1.745, \mathrm{df}=3, \mathrm{p}>.05(.627)$} \\
\hline & & UM & $33(11.3 \%)$ & $161(55.3 \%)$ & $97(33.3 \%)$ & \\
\hline \multirow{2}{*}{ Q8 } & \multirow{2}{*}{$\begin{array}{l}\text { Students' perceptions of their responsibility } \\
\text { to decide how long to spend on activity }\end{array}$} & $\mathrm{M}$ & $115(17.1 \%)$ & $360(53.9 \%)$ & $192(28.6 \%)$ & \multirow{2}{*}{$\mathrm{x}^{2}=.677, \mathrm{df}=3, \mathrm{p}>.05(.879)$} \\
\hline & & $\mathrm{UM}$ & $49(16.8 \%)$ & $155(53.2 \%)$ & $87(29.8 \%)$ & \\
\hline \multirow{2}{*}{ Q9 } & \multirow{2}{*}{$\begin{array}{l}\text { Students' perceptions of their responsibility } \\
\text { to choose materials to use in lessons }\end{array}$} & $\mathrm{M}$ & $46(6.8 \%)$ & $472(70.2 \%)$ & $149(22.3 \%)$ & \multirow{2}{*}{$x^{2}=1.776, d f=3, p>.05(.620)$} \\
\hline & & UM & $19(6.5 \%)$ & $217(74.5 \%)$ & $55(19.5 \%)$ & \\
\hline \multirow{2}{*}{ Q10 } & \multirow{2}{*}{$\begin{array}{l}\text { Students' perceptions of their responsibility } \\
\text { to evaluate learning }\end{array}$} & M & $39(5.8 \%)$ & $366(54.5 \%)$ & $262(39 \%)$ & \multirow{2}{*}{$\mathrm{x}^{2}=11.297^{*}, \mathrm{df}=4, \quad * \mathrm{p}<.05(.023)$} \\
\hline & & UM & $21(7.2 \%)$ & $187(64.2 \%)$ & $83(29 \%)$ & \\
\hline
\end{tabular}

$\mathrm{M}=$ Motivated; UM = Unmotivated; $\mathrm{SR}=$ Student's responsibility; TR = Teacher's responsibility; $\mathrm{B}$ = Both; $\mathrm{n}=$ total number of respondents 
Table 2: Perceptions of ability

\begin{tabular}{|c|c|c|c|c|c|}
\hline & Autonomy-Related Tasks (Ability) & $\begin{array}{l}\text { Moti- } \\
\text { vation } \\
\text { Level }\end{array}$ & $\begin{array}{l}\text { Able To } \\
\text { n (\%) }\end{array}$ & $\begin{array}{c}\text { Not Able To } \\
\text { n }(\%)\end{array}$ & Note \\
\hline \multirow{2}{*}{ Q1 } & \multirow{2}{*}{$\begin{array}{l}\text { Students' perceptions of their ability to } \\
\text { make progress during English lessons }\end{array}$} & M & $476(71.3 \%)$ & $191(28.6 \%)$ & \multirow{2}{*}{$\mathrm{x}^{2}=59.531 *, \mathrm{df}=4, * \mathrm{p}<.001(.000)$} \\
\hline & & UM & $136(46.7 \%)$ & $155(53.2 \%)$ & \\
\hline \multirow{2}{*}{ Q2 } & \multirow{2}{*}{$\begin{array}{l}\text { Students' perceptions of their ability to } \\
\text { ensure progress outside class }\end{array}$} & M & $442(66.2 \%)$ & $225(33.7 \%)$ & \multirow{2}{*}{$\mathrm{x}^{2}=67.912 *, \mathrm{df}=4, \quad * \mathrm{p}<.001(.000)$} \\
\hline & & UM & $132(45.3 \%)$ & $159(54.6 \%)$ & \\
\hline \multirow{2}{*}{ Q3 } & \multirow{2}{*}{$\begin{array}{l}\text { Students' perceptions of their ability to } \\
\text { stimulate interests }\end{array}$} & M & $510(76.4 \%)$ & $157(23.5 \%)$ & \multirow{2}{*}{$\mathrm{x}^{2}=138.550 *, \mathrm{df}=6, * \mathrm{p}<.001(.000)$} \\
\hline & & UM & $155(53.2 \%)$ & $136(46.7 \%)$ & \\
\hline \multirow{2}{*}{ Q4 } & \multirow{2}{*}{$\begin{array}{l}\text { Students' perceptions of their ability to } \\
\text { identify weakness }\end{array}$} & M & $492(73.7 \%)$ & $175(26.2 \%)$ & \multirow{2}{*}{$\mathrm{x}^{2}=84.906^{*}, \mathrm{df}=4,{ }^{*} \mathrm{p}<.001(.000)$} \\
\hline & & UM & $151(51.8 \%)$ & $140(48.1 \%)$ & \\
\hline \multirow{2}{*}{ Q5 } & \multirow{2}{*}{$\begin{array}{l}\text { Students' perceptions of their ability to } \\
\text { decide objectives of class }\end{array}$} & M & $443(66.4 \%)$ & $224(33.5 \%)$ & \multirow{2}{*}{$\mathrm{x}^{2}=37.003 *, \mathrm{df}=4, * \mathrm{p}<.001(.000)$} \\
\hline & & $\mathrm{UM}$ & $141(48.4 \%)$ & $150(51.5 \%)$ & \\
\hline \multirow{2}{*}{ Q6 } & \multirow{2}{*}{$\begin{array}{l}\text { Students' perceptions of their ability to } \\
\text { decide what to learn next in the lesson }\end{array}$} & M & $443(66.4 \%)$ & $224(33.5 \%)$ & \multirow{2}{*}{$\mathrm{x}^{2}=78.229^{*}, \mathrm{df}=6, * \mathrm{p}<.001(.000)$} \\
\hline & & UM & $129(44.3 \%)$ & $162(55.6 \%)$ & \\
\hline \multirow{2}{*}{ Q7 } & \multirow{2}{*}{$\begin{array}{l}\text { Students' perceptions of their ability to } \\
\text { choose activities to use in lessons }\end{array}$} & M & $456(68.3 \%)$ & $211(31.6 \%)$ & \multirow{2}{*}{$\mathrm{x}^{2}=89.504 *, \mathrm{df}=4, * \mathrm{p}<.001(.000)$} \\
\hline & & $\mathrm{UM}$ & $127(43.6 \%)$ & $164(56.3 \%)$ & \\
\hline \multirow{2}{*}{ Q8 } & \multirow{2}{*}{$\begin{array}{l}\text { Students' perceptions of their ability to } \\
\text { decide how long to spend on activity }\end{array}$} & $\mathrm{M}$ & $453(67.9 \%)$ & $214(32 \%)$ & \multirow{2}{*}{$\mathrm{x}^{2}=92.868 *, \mathrm{df}=4, * \mathrm{p}<.001(.000)$} \\
\hline & & UM & $141(48.7 \%)$ & $149(51.2 \%)$ & \\
\hline \multirow{2}{*}{ Q9 } & \multirow{2}{*}{$\begin{array}{l}\text { Students' perceptions of their ability to } \\
\text { choose materials to use in lessons }\end{array}$} & M & $476(71.3 \%)$ & $191(28.6 \%)$ & \multirow{2}{*}{$\mathrm{x}^{2}=71.156^{*}, \mathrm{df}=4,{ }^{*} \mathrm{p}<.001(.000)$} \\
\hline & & UM & $127(44.4 \%)$ & $164(56.3 \%)$ & \\
\hline \multirow{2}{*}{ Q10 } & \multirow{2}{*}{$\begin{array}{l}\text { Students' perceptions of their ability to } \\
\text { evaluate learning }\end{array}$} & M & $469(70.3 \%)$ & $198(29.6 \%)$ & \multirow{2}{*}{$\mathrm{x}^{2}=47.973^{*}, \mathrm{df}=4, * \mathrm{p}<.001(.000)$} \\
\hline & & UM & $144(49.4 \%)$ & $147(50.5 \%)$ & \\
\hline
\end{tabular}

$\mathrm{M}=$ Motivated; $\mathrm{UM}=$ Unmotivated; $\mathrm{n}=$ total number of respondents

Regarding the perception of ability, Table 2 shows that significant differences were evident in all 10-item responses between motivated and unmotivated participants. For Q1, making progress during English lessons $\left(\chi^{2}=59.531 *\right.$, df $=4, * p<.001$ (.000)), the majority of $\mathrm{M}$ participants $(71.3 \%)$ perceived themselves as capable of making progress during English lessons while less than half of the UM participants (46.5\%) believed they could perform the task. For Q2, ensuring progress outside class $\left(\chi^{2}=67.912 *\right.$, df $=4$, $* \mathrm{p}<.001(.000))$, more than half of $\mathrm{M}$ participants $(66.2 \%)$ perceived themselves as capable of making progress during English lessons while less than half of the UM participants $(45.3 \%)$ believed they could perform the task. For Q3, stimulating interests $\left(\chi^{2}=138.550 *, \mathrm{df}=6, * \mathrm{p}<.001(.000)\right)$, the majority of M participants $(76.4 \%)$ perceived themselves as capable of stimulating interests while only a little over half of the UM participants $(53.2 \%)$ believed they could perform the task. For Q4, identifying weakness $\left(\chi^{2}=84.906^{*}, \mathrm{df}=4, * \mathrm{p}<.001(.000)\right)$, the majority of M participants $(73.7 \%)$ perceived themselves as capable of identifying weaknesses while only a little over half of the UM participants $(51.8 \%)$ believed they could perform the task. For Q5, deciding objectives of class $\left(\chi^{2}=37.003^{*}\right.$, $\left.\mathrm{df}=4, * \mathrm{p}<.001(.000)\right)$, more than half of $\mathrm{M}$ participants $(66.4 \%)$ perceived themselves as capable of deciding objectives of class while less than half of the UM participants $(48.4 \%)$ believed they could perform the task. For Q6, deciding what to learn next in the lesson $\left(\chi^{2}=78.229 *\right.$, df $\left.=6, * p<.001(.000)\right)$, more than half of $\mathrm{M}$ participants $(66.4 \%)$ perceived themselves as capable of deciding what to learn next in the lesson while less than half of the UM participants $(44.3 \%)$ believed 
they could perform the task. For Q7, choosing activities to use in lessons $\left(\chi^{2}=89.504 *\right.$, $\mathrm{df}=4, * \mathrm{p}<.001(.000))$, more than half of $\mathrm{M}$ participants $(68.1 \%)$ perceived themselves as capable of choosing activities to use in lessons while less than half of the UM participants $(43.4 \%)$ believed they could perform the task. For 8, deciding how long to spend on activity $\left(\chi^{2}=92.868^{*}, \mathrm{df}=4, * \mathrm{p}<.001(.000)\right)$, more than half of $\mathrm{M}$ participants $(67.5 \%)$ perceived themselves as capable of deciding how long to spend on an activity while less than half of the UM participants $(48.3 \%)$ believed they could perform the task. For Q9, choosing materials to use in lessons $\left(\chi^{2}=71.156^{*}\right.$, df $=4$, ${ }^{*} p<.001(.000)$ ), the majority of $\mathrm{M}$ participants $(70.9 \%)$ perceived themselves as capable of choosing materials to use in lessons while less than half of the UM participants $(44.4 \%)$ believed they could perform the task. Finally, for Q10, evaluating learning $\left(\chi^{2}=47.973 *\right.$, df $=4$, $* p<.001(.000))$, the majority of M participants $(70 \%)$ perceived themselves as capable of evaluating learning while less than half of the UM participants (49.3\%) believed they could perform the task.

\section{Discussion}

The discussion section will look at the two main facets of learner autonomy, responsibility and ability, and focus on the students' perceptions of these two concepts and the differences between motivated and unmotivated students.

\subsection{Responsibility for autonomous learning tasks}

The results from the answers to a set of 10 items based on responsibility to carry out autonomous learning tasks revealed minimal significant difference in responses between motivated and unmotivated participants. Responses by both groups of participants for each of the 10 statements reveal some awareness of autonomous learning. However, both motivated and unmotivated participants relinquished the majority of tasks to the teacher, which suggests a failure to recognize that responsibility for autonomous learning tasks lies with both the student and teacher. Thus, there are several points of interest worth further discussion in relation to specific tasks.

Regarding specific statement items, the majority of participants from both motivation groups felt that responsibility should be shared in one task only, Q1, making progress in the classroom, which may be a false belief among the participants. Regarding Japanese EFL learners specifically, Usuki (2002) concluded in her study that student attitudes or behaviors may change often or are influenced by the situation they find themselves in. In certain settings, for example in a classroom where the teacher is present, they may feel they need to be active and that responsibility for learning must lie with both, but in other situations like outside the classroom, they may remain passive. Similar assumptions may be made regarding Q3, stimulating interests. Additionally, as seen in Q2, ensuring learning outside the classroom, the majority of both M participants and UM participants felt the responsibility rested with the learners themselves, perhaps only for the obvious fact that the teacher is not present. This supports the results from a previous study by 
Gamble et al. (2011) in their study with 399 Japanese EFL learners in which they found that regardless of motivation level, all participants believed learning outside the classroom was the student's responsibility only. Therefore, this may also demonstrate a misunderstanding or false perception of responsibility among the participants.

Statement items related to classroom management (Q5, Q6, Q7, Q8, Q9) seem to confirm some of the conclusions made about East Asian learners. As teachers are viewed as authority figures specifically and not necessarily facilitators of learning, East Asian learners, including Japanese, tend to expect the teachers to make decisions regarding their learning (Holden \& Usuki 1999; Littlewood 1999; Sakai et al. 2008; Orawiwatnakul \& Wichadee 2017). This may or may not be true for the participants of this study, as in order for learners to take on responsibility, they must first be given the opportunity to make decisions that directly influence their learning; decisions that are usually overseen by the teacher (Littlewood 1999; Sakai et al. 2008). Interestingly, the overall perceptions made by $M$ participants seem to reflect the conclusions made by Gamble et al. (2011) and Ustunluoglu (2009), who surmised that students who perceive themselves as being motivated to learn neither want to nor are willing to engage autonomously. In both studies, a lack of confidence by the students was reported. For Japanese EFL learners specifically, this could be, according to Usuki (2002), because of a psychological barrier in which they recognize what they need to do but feel they cannot act on it. Keim et al. (1996: 99) added that for Japanese learners of English, "fear and insecurity play a significant role in the way students behave in class, even though they genuinely wish to improve their English and, in some cases, would actually like to behave differently". These conclusions about Japanese learners may help explain to a certain extent why $\mathrm{M}$ participants in this study seemed to understand the role of their responsibility in a few tasks, but not in a majority of them - making their beliefs similar to the beliefs of UM participants and thus indicating no significant differences between them.

\subsection{Ability to carry out autonomous learning tasks}

Unlike the conclusions made regarding student perceptions of responsibility, far greater implications lie with the results on the set of 10 items concerning the ability to carry out autonomous learning tasks. Regarding ability, significant differences were evident in all 10-item responses between motivated and unmotivated participants. Most notable is the fact that a substantial majority of $\mathrm{M}$ participants felt they were capable of handling all related autonomous learning tasks. In contrast, UM participants felt they were only able to do two tasks, stimulating interests (Q3) and identifying weakness (Q4). Thus, UM participants demonstrated little to no confidence in eight of the ten autonomous learning tasks. This is meaningful if not for the simple fact that, "at the heart of all learning is a person's belief in his or her ability to accomplish the task" (Brown 2001: 62).

For $\mathrm{M}$ participants of this study, they clearly have a sense of self-confidence in their ability to do autonomous learning tasks, yet as discussed previously, their attitudes to their responsibility for such tasks do not match their confidence in ability. This is significant for several reasons as responses from the majority of $\mathrm{M}$ participants for all tasks related to ability demonstrated some capacity and understanding for autonomous learning, 
which both supports (Holden \& Usuki 1999; Littlewood 2000; Usuki 2002; Gamble et al. 2011) and contradicts (Healey 1999) conclusions from previous research on East Asian learners. For example, Healey stated that learner self-direction and autonomous learning are Western concepts. This would imply that the participants of this study are incapable of being autonomous, but a more accurate claim would be that they are capable of autonomous learning, but have limitations or, more predictably, they may have limitations placed upon them. Additionally, Holden \& Usuki (1999) also claim that while students are aware of and have some understanding of metacognitive and/or communicative language learning strategies, they tend to falter in their ability to apply this knowledge practically. Specifically, Holden and Usuki postulate that, "students have a conception of themselves as independent learners and have metacognitive awareness of various means which can be used to facilitate learning, but are unclear as how to actually apply this knowledge to the task of learning" (p. 196). The findings of this study, related to ability, further support suggestions made in the previous section, namely that $M$ participants in particular seem to understand the importance of autonomous learning tasks, feel they are able to do them, yet they do not know how to fully take responsibility for their learning. This revelation seems to support previous conclusions by Aliponga et al. (2015), Littlewood (2000), and Ustunluoglu (2009), in that the teachers themselves may limit their students' capacity to accomplish such autonomous learning tasks. Therefore, there is a specific need for teachers to encourage such motivated students more or show them that they can achieve their learning goals on their own. These students would greatly benefit from more opportunities to demonstrate their self-belief in their ability.

While M participants demonstrated a belief in their ability to accomplish autonomous learning tasks, UM participants clearly lacked confidence in their ability to accomplish the same tasks. In other words, they have little confidence in their ability where it matters most. The findings of this study suggest that UM participants are most in need of teacher guidance in developing their abilities, which is necessary for taking on more responsibility for their learning. It is also essential to show these students how important their involvement is for their own learning.

\section{Conclusion, implications, and recommendations}

This section will sum up the findings and their limitations and explore implications for language teachers when endeavoring to foster learner autonomy in the classroom. The authors will make a few recommendations on how to accomplish this.

\section{Recommendations}

Based on the conclusions made from the previous research and from this study, several recommendations can be made. As regards to responsibility, there is a strong need for teachers to encourage more student responsibility by helping students to become more aware of the importance of their roles in making decisions regarding their learning (Pope- 
scu \& Cohen-Vida 2014). Sakai et al. (2010) support this by stating that students should be given more of a voice on decisions over classroom or course management. For example, teachers could try relinquishing some of the tasks that students usually presume to be solely theirs, for example deciding what to learn in lessons or the amount of homework given, while showing confidence that the students will be able to handle such responsibilities. Furthermore, by allowing students more control over their learning, they will inevitably accept more responsibility (Dickinson 1995; Fazey \& Fazey 2001) and gaining more ownership over their own outcomes will improve self-motivation (McCombs 2012). Small steps such as this are vital for student progress, as Chan (2003) suggests that as learners become more autonomous they are expected to take charge of every level of their learning.

This seems to resonate particularly true for unmotivated students. According to Scharle and Szabo (2000), motivation and responsibility mutually reinforce each other, so encouraging greater student motivation will equally influence and support students to take on more responsibility for their own learning outcomes.

Regarding unmotivated students, according to the data in this study, there is ample room in the typical Japanese university classroom for opportunities to improve classroom environments and the social dynamics in which students and teachers engage with each other during lessons. Changes to curriculum design or pedagogical approaches should include educating and training these types of students in learning strategies to narrow the gap between their perceived abilities and the learning responsibilities they take on. Additionally, motivational strategies, such as creating and implementing more intimate opportunities for students to engage in tasks together, is recommended in order to reduce student stress and anxiety and to allow them to try things on their own with the support of a small group of peers.

Individual self-motivation plays a key role in developing learner autonomy, Bandura's (1977) 'self-efficacy theory' has since been expanded to include learner strategies (Cotterall 1999, 2000; Ehrman et al. 2003). Thus, in order to help guide unmotivated students towards fully developing their abilities and improving their confidence, teachers should first consider educating them on the importance of learning strategies. Learning strategies according to Oxford et al. (1993: 36), "are specific behaviors that students use to enhance their language learning" and Scharle and Szabo (2000) point out that developing the ability to utilize learning strategies is necessary for students to take responsibility for their own learning. Thus, empowering unmotivated students by training them to use learning strategies can help lead them towards learner independence. However, considering the educational contexts usually found in Asia, patience must be stressed, according to Kamada (1987: 22), who explained: "In Japanese society and Japanese schools, independence is a skill which cannot be taken for granted. Independence itself must be taught first as a learning strategy skill before students can learn how to become independent learners where they take responsibility for their own learning".

Along with learner strategy training, teachers should also consider either changing or incorporating new curriculum and pedagogical approaches to help unmotivated students continue to improve their confidence and in turn take on more responsibility for their own learning. As Oxford (1990: 142) contends, "[a] certain amount anxiety sometimes 
helps learners to reach their peak performance levels, but too much anxiety blocks language learning". As discussed earlier regarding Bandura's (1977) 'self-efficacy theory,' motivated students will see tasks as challenges, while unmotivated students or students with low confidence in their ability will see them as obstacles and thus feel stressed or anxious about their learning. Therefore, one way to ease student anxiety and build confidence so these students become more independent and responsible learners is to incorporate student-centered activities where students engage in meaningful and purposeful contexts (Atsuda 2003) and within a classroom that is friendly and students are intimately connected with each other and the teacher (Noels 2003; Adamson 2004; Benson \& Voller 2014; Lengkanawati 2017). Specifically, several studies emphasise that collaboration (Adamson 2004) and cooperative learning (Crandall 1999; Atsuda 2003) help reduce anxiety and promote motivation and self-confidence, especially among weaker students. Thus, allowing students with low confidence to participate in and complete tasks in pairs or small groups, where more communicative or cooperative interaction with their peers can take place, will reduce individual pressure to succeed and greatly benefit learning in the long term. Thus, while motivated students might only need more positive encouragement and assistance on how to further take more responsibility during tasks, unmotivated students first need to be made more aware of the importance of their role in making decisions regarding their learning. Additionally, they require more collaboration with other learners on tasks to help build confidence and teachers need to consider incorporating learner strategies to help improve student self-efficacy in order to increase motivation and ultimately take on more responsibility for their own learning. Therefore, the need to show students, regardless of their motivational level, that they can achieve it on their own and to teach them learning strategies, can lead to greater autonomous learning.

\section{Conclusions}

This study attempted to identify and examine differences in Japanese university EFL learners' perceptions of their responsibilities and abilities to carry out autonomous learning tasks in relation to their own self-perceived motivation levels. While there was little evidence of significant differences related to responsibility, results based on perceptions of ability yielded significant differences between motivated and unmotivated students.

Regarding responsibility for autonomous learning tasks, the majority of students, regardless of motivation, relinquished responsibility for learning to the teacher on a majority of tasks. It is not necessarily a surprise that participants in this study do not perceive themselves as sufficiently capable of taking responsibility, as Asian students are more often than not accustomed to learning in a teacher-centered classroom and hold teachers in high esteem, and thus, often the source of all knowledge. Interesting enough though is that motivated participants felt similar to that of unmotivated participants even though they felt capable in their ability to accomplish the same tasks. Thus, as Wachob (2006: 110) concludes, "motivation and self-efficacy... can suffer if students cannot feel in control of their own learning". This study therefore highlights the need for teachers to provide more opportunities that encourage learner independence through changes in course 
curriculum or pedagogical approaches and these suggestions mirror the recommendations made in studies by Ustunluoglu and Ou. Ou (2017: 78) concludes that, "[t]eachers should develop students' self-efficacy during language teaching in order to achieve greater learner autonomy" while Ustunluoglu (2009: 162) postulates further by adding, "[r]especting student ideas, sharing decisions in teaching, learning goal setting, and leading students towards taking responsibility for their learning rather than prescribing the learning process will all increase student motivation, and thus, foster success".

As far as the ability to carry out autonomous learning tasks is concerned, the findings reveal significant differences based on motivation. The results of this study showed that motivated students felt capable of doing all autonomous learning tasks, but perhaps were not given the opportunity to take responsibility for such tasks. Holden \& Usuki (1999) support this by surmising that Japanese learners demonstrate the same capabilities to be autonomous as any other learners with culturally different backgrounds and that educational contexts or behavioral norms towards language study in Japan may in fact impede opportunities for learner autonomy. Thus, for students who are motivated and who are ready to take on more responsibility for their own learning, the recommendations made in this study for implementing new pedagogical approaches to improve student opportunities for self-engagement can be summed up best by Littlewood (1999), who postulates that East Asian learners, similarly to their Western counterparts, have the same potential for autonomous learning when teachers provide the right type environment that stimulates learner autonomy rather than hinders it.

Regarding the perceptions of UM participants in this study, they demonstrated some confidence in their ability to accomplish a few autonomous learning tasks. However, their perceived lack in overall ability to be more involved in their own learning, along with some inconsistency in their understanding of and beliefs in their responsibility for the same tasks demonstrates a real need for teachers to address these issues firsthand. As discussed above, by providing various types of strategy training to these students that need them, they will be better encouraged to make more choices on their own, build their confidence about self-determination and be more willing to take more responsibility on their way towards autonomous learning (McCombs 2012).

\section{Limitations}

Based on a study with such a large sample size, a number of possible limitations can be made. However, the researchers of this study have highlighted only a few in particular. The type of motivation observed in this study can be considered a limitation. Our study did not investigate or differentiate among motivation types, and instead, directly adapted original questionnaire items from Ustunluoglu's (2009) study, including questions that asked students to self-assess their own motivation. The perceived motivation levels in this study might reflect Japanese students' general hesitance to honestly gauge their own level of skills, abilities, and motivations and so relying on self-perception alone must be recognized as a limitation. Another limitation along similar lines is that this study did not look at gender differences with regard to both beliefs of responsibility and ability 
based on motivation. This large study had almost an equal number of male and female participants and thus self-perceived motivation levels could have been further categorized based on gender and then the data could have been analyzed with this factor in mind. Perhaps further studies could continue the research through new questions that focus on gender differences and motivation in relation to autonomous learning tasks. A final limitation we would like to highlight in this study is the acknowledgement that our research is based solely on quantitative research with no qualitative component utilized to further validate conclusions such as interviews with students and teachers as in Ustunluoglu's (2009) study. The rationale of this study was to collect and analyze a large collection of data in order to show the overall tendencies among Japanese students to self-evaluate perceived responsibilities and abilities in relation to their motivation. The researchers successfully compiled a quantitative sample size large enough to analyze the research goals of this study. Therefore, in future studies, the next step would be to thoroughly investigate further the major factors in Japanese tertiary education that negatively affect student confidence or disparage responsibility to act on autonomous learning tasks.

\section{Author note}

This study is a continuation of a pilot study conducted and published in the JALT 2011 Conference Proceedings. In this article the data were gathered from one thousand and twenty-one participants, while the data for the JALT 2011 Conference Proceedings was from three hundred ninety-nine participants.

Gamble, Craig \& Aliponga, Jonathan \& Wilkins, Michael \& Koshiyama, Yasuko \& Yoshida, Keiko \& Ando, Shirley. 2011. Examining Learner Autonomy Dimensions: Students' Perceptions of Their Responsibility and Ability. In Alison, Stewart \& Nozomu, Sonda (eds.), JALT 2011 Conference Proceedings. 262-272. Tokyo: JALT.

\section{References}

Adamson, John. 2004. Investigating college student attitudes towards learning English and their learning strategies: Insights from Interviews in Thailand. Journal of Asia TEFL 1(2). 47-70.

Aliponga, Jonathan \& Koshiyama, Yasuko \& Gamble, Craig \& Yoshida, Keiko \& Wilkins, Michael \& Ando, Shirley. 2015. Learner autonomy in Japanese high schools: An exploratory study. International Journal of Self-Directed Learning 12(1). 29-40.

Atsuta, Hiromi. 2003. Improving the motivation of unsuccessful learners in the Japanese high school EFL Context. ERIC Document Reproduction Service No. ED 476 750. 1-35.

Bandura, A. 1977. Self-efficacy: toward a unifying theory of behavioral change. Psychological Review 84(2). 191-215.

Benson, Phil \& Voller, Peter. 2014. Autonomy and independence in language learning. London: Routledge.

Brown, Douglas H. 2001. Teaching by principles: An interactive approach to language pedagogy. New York: Addison Wesley Longman.

Biggs, John. 1994. What are effective schools? Lessons from East and West. Australian Educational Researcher 21(1). 19-59.

Chan, Victoria. 2003. Autonomous language learning: The teachers' perspectives. Teaching in Higher Education 8(1). 33-54.

Chan, Victoria \& Spratt, Mary \& Humphreys, Gillian. 2002. Autonomous language learning: Hong Kong tertiary students' attitudes and behaviours. Evaluation and Research in Education 16(1). 1-18

Cotterall, Sara. 1995. Readiness for autonomy: Investigating learner beliefs. System 23(2). 195-206. 
Cotterall, Sara. 1999. Key variables in language learning: what do learners believe about them? System 27(4). 493-513.

Cotterall, Sara. 2000. Promoting learner autonomy through the curriculum: Principles for designing language courses. ELT Journal 54(2). 109-117.

Crandall, JoAnn. 1999. Cooperative language and learning affective factors. In Arnold, Jane (ed.), Affect in Language Learning, 226-245. Beijing: Cambridge University Press.

Deci, Edward \& Ryan, Richard. 1985. Intrinsic motivation and self-determination in human behavior. New York: Plenum Press.

Deci, Edward. 1995. Why we do what we do: The dynamics of personal autonomy. New York: Putnam's Sons.

Dickinson, Leslie. 1995. Autonomy and motivation a literature review. System 23(2). 165-174.

Ehrman, Madeline \& Leaver, Betty Lou \& Oxford, Rebecca. 2003. A brief overview of individual differences in second language learning. System 31(4). 313-330.

Fazey, Della \& Fazey, John. 2001. The potential for autonomy in learning. Studies in Higher Education 26(3). 345-361.

Gamble, Craig \& Aliponga, Jonathan \& Wilkins, Michael \& Koshiyama, Yasuko \& Yoshida, Keiko \& Ando, Shirley. 2011. Examining Learner Autonomy Dimensions: Students' Perceptions of Their Responsibility and Ability. In Stewart, Alison \& Sonda, Nozomu (eds.), JALT2011 Conference Proceedings, 262-272. Tokyo: JALT.

Haughton, Gillies \& Dickinson, Leslie. 1988. Collaborative assessment by masters' candidates in a tutor based system. Language Testing 5. 233-246.

Healey, Deborah. 1999. Theory and research: Autonomy in language learning. In Egbert, John \& Hanson-Smith, Elizabeth (eds.), CALL Environments: Research, Practice and Critical Issues. 391-402. Alexandria, VA: TESOL.

Holden, Bill \& Usuki, Miyuki. 1999. Learner autonomy in language learning: A preliminary investigation. Bulletin of Hokuriku University 23. 191-203.

Holec, Henri. 1981. Autonomy and Foreign Language Learning. Oxford: Pergamon.

Kamada, Laurel Diane. 1987. Intrinsic and extrinsic motivational learning process: Why Japanese can't speak English. Paper presented at the Japan Association of Language Teachers' International Conference on Language Teaching and Learning, Seirei Gakuen, Hamamatsu, Japan.

Keim, Bob \& Furuya, Reiko \& Doye, Chris. 1996. A Survey of the Attitudes and Beliefs About Foreign Language Learning of Japanese University Students Taking Communicative English Courses. Jacet Bulletin 27. 87-106.

Kumaravadivelu, B. 1991. Language-learning tasks: teacher intention and learner interpretation. ELT Journal 45(2). 98-107.

Lengkanawati, Nenden Sri. 2017. Learner autonomy in the Indonesian EFL settings. Indonesian Journal of Applied Linguistics 6(2). 222-231.

Little, David. 1995. Learning as dialogue: The dependence of learner autonomy on teacher autonomy. System 23(2). 175-181.

Littlewood, William. 1999. Defining and developing learner autonomy in East Asian contexts. Applied Linguistics 20(1). 71-94.

Littlewood, William. 2000. Do Asian students really want to listen and obey? ELT Journal 54(1). 31-36.

Liu, Dilin. 1998. Ethnocentrism in TESOL: Teacher education and the neglected needs of international TESOL students. ELT Journal 52(1). 3-10.

McCombs, Barbara. 2012. Developing responsible and autonomous learners: A key to motivating students. http://www.apa.org/education/k12/learners.aspx). (Accessed 2018-07-21.)

Noels, Kimberly A. 2003. Learning Spanish as a second language: learners' orientations and perceptions of their teachers' communication style. Language Learning 5. 97-136.

Orawiwatnakul, Wiwat \& Wichadee, Saovapa. 2017. An investigation of undergraduate students' beliefs about autonomous language learning. International Journal of Instruction 10(1). 117-132.

Ou, Chuying. 2017. A review on language learner autonomy research in China (2006-2016): Based on 12 key domestic journals. English Language Teaching 10(11). 76-86.

Oxford, Rebecca. 2008. Hero with a thousand faces: Learner autonomy, learning strategies and learning tactics in independent language learning. In Hurd, Stella \& Lewis, Tim (eds.), Language Learning Strategies in Independent Settings, 41-66. Clevedon, UK: Multilingual Matters Ltd. 
Oxford, Rebecca \& Park-Oh, Young, \& Ito, Sukero \& Sumrall, Malenna. 1993. Learning a language by satellite television: What influences student achievement? System 21(1). 31-48.

Popescu, Alexandra-Valeria \& Cohen-Vida, Marion-Ivonne. 2014. Communication strategies for developing the learner's autonomy. Social and Behavioral Sciences 116. 3489-3493.

Sakai, Shien \& Takagi, Akiko, \& Chu, Man-Ping. 2010. Promoting learner autonomy: Student perceptions of responsibilities in a language classroom in East Asia. Educational Perspectives 43(1-2). 12-27.

Sakai, Shien \& Chu, Man-Ping \& Takagi, Akiko, \& Lee, Seongwon. 2008. Teachers roles in developing learning autonomy in the East Asian Region. The Journal of ASIA TEFL 5(1). 93-117.

Scharle, Agota \& Szabo, Anita. 2000. Learner autonomy: A guide to developing learner responsibility. Cambridge: Cambridge University Press.

Sert, Nehir. 2006. EFL Student Teachers' Learning Autonomy. In Robertson, Paul \& Jung, Joseph (eds.), The Asian EFL Journal Quarterly 8(2). 180-201. British Virgin Islands: Asian EFL Journal Press.

Tran, Thao Quoc \& Tham, My Duong. 2018. EFL learners' perceptions of factors influencing learner autonomy development. Kasetsart Journal of Social Sciences. https://doi.org/10.1016/j.kjss.2018.02.009.

Ustunluoglu, Evrim. 2009. Autonomy in language learning: Do students take responsibility for their learning? Journal of Theory and Practice in Education 5(2). 148-169.

Usuki, Miyuki. 2002. Learner autonomy: Learning from the student's voice. CLCS Occasional Paper. No. 60. Autumn 2002. Dublin: Trinity College Dublin, Centre for Language and Communication Studies.

Wachob, Phyllis. 2006. Methods and materials for motivation and learner autonomy. Reflections on English Language Teaching 5(1). 93-122. 